\title{
CHLOROPHYLL FLUORESCENCE OF BASIL PLANTS CULTIVATED IN A HYDROPONIC SYSTEM USING TREATED DOMESTIC WASTEWATER
}

\author{
Karoline S. Gonçalves ${ }^{*}$, Lucylia S. Alves², Vital P. da S. Paz ${ }^{2}$, Samir de S. Bandeira²
}

\author{
${ }^{1 *}$ Corresponding author. Universidade Federal do Recôncavo da Bahia/ Cruz das Almas - BA, Brasil. \\ E-mail: karolinesg@yahoo.com.br | ORCID ID: http://orcid.org/0000-0002-1124-9309
}

\section{KEYWORDS}

wastewater, Ocimum

basilicum L.,

photosynthetic

response.

\begin{abstract}
Different techniques have been used to evaluate the energetic characteristics and damage to the photosynthetic apparatus of plants exposed to different stresses, including the measurement of chlorophyll fluorescence. The objective of this study is to evaluate the photosynthetic response by assessing the fluorescence parameters of chlorophyll $a$ in basil (Ocimum basilicum L.) cv. Alfavaca Basilicão cultivated in a hydroponic deep-flow technique system using treated domestic wastewater. The study used a completely randomized block design with a $2 \times 2$ factorial scheme, in which the factors were the water source used for preparing the nutrient solution (tap water or treated domestic wastewater) and the height (upper and lower) of the platform of the cultivation system. The photosynthetic yield of the plants grown on the lower platform was comparatively lower regardless of the water source. However, there was no significant effect of the water source on the potential and effective quantum yields of photosystem II, indicating the absence of changes in the photosynthetic apparatus and photosynthetic yield of plants produced with treated domestic wastewater, suggesting the viability of this treatment for producing basil cv. Alfavaca Basilicão in hydroponic systems.
\end{abstract}

\section{INTRODUCTION}

The genus Ocimum has a high agronomic potential for the production and extraction of essential oil, and medicinal and aromatic use (Alcântara et al., 2018). The yield, concentration, and composition of the essential oils of basil plants grown in different environmental and cultivation conditions are well known; however, few studies to date evaluated the physiological response of this plant genus to hydroponic cultivation, especially using wastewater.

Changes in environmental and cultivation conditions force the photosynthetic system of plants to adapt and change their physiological state. The amount and quality of the water supplied to plants can modify the rate of electron transport and the efficiency of light transfer during photosynthesis, affecting crop productivity (Oukarroum et al., 2007). Different techniques have been used to determine the energetic performance and damage to the photosynthetic apparatus in plants exposed to different stresses, including the evaluation of the fluorescence parameters of chlorophyll $a$.

Chlorophyll fluorescence provides fast, efficient, and non-destructive information on the conversion, transfer, and dissipation of light energy in photosystem II (PSII), allowing the analysis of photochemical efficiency and damage to the structure and functioning of the photosynthetic apparatus (Martinazzo et al. 2012). Fluorimetry is used in this type of analysis and allows the identification of damage to the photosynthetic apparatus and the measurement of changes in the photosynthetic performance of plants (Araldi et al., 2015).

Water availability is one of the main factors affecting plant growth and development. In the semi-arid region of the northeast of Brazil, low water availability, poor distribution of rainfall, and high temperatures limit crop development. Therefore, wastewater is used to mitigate the effects of water scarcity in this region, making crop development possible and profitable.

Domestic and industrial effluents improve the use of irrigation water and the nutritional potential of crops in an economically and environmentally sustainable manner. Reuse water has economic benefits in agriculture, including the minimization of sewage discharge into water bodies and high fertilizing potential. Moreover, most treated effluents are rich in minerals and organic matter, which are necessary for plant development (Sandri \& Rosa, 2017).

\footnotetext{
${ }^{2}$ Universidade Federal do Recôncavo da Bahia/ Cruz das Almas - BA, Brasil.

Received in: 12-13-2017

Accepted in: 3-3-2019
} 
It is essential to choose the appropriate irrigation system with reuse water to reduce the risk of human and environmental contamination, considering the possible adverse effects of these water systems in the soil and water by increasing soil salinity and contaminating water bodies. Wastewater is used in closed systems, including hydroponic systems, to grow medicinal, ornamental, and food plant species because it has an adequate amount of nutrients and reduces the risk of contamination (Santos Júnior et al., 2014; Cuba et al., 2015; Albuquerque Júnior et al., 2016). The increased interest in hydroponics and wastewater underscores the need to further investigate the development and management of crops to establish criteria on plant density and arrangement in each cultivation system and the quality of the water used for preparing the nutrient solution.

The objective of this study is to evaluate the photosynthetic response by analyzing fluorescence parameters of chlorophyll $a$ in basil (Ocimum basilicum cv. Alfavaca Basilicão) cultivated in a hydroponic deepflow technique (DFT) system using treated domestic wastewater.

\section{MATERIAL AND METHODS}

This study is part of the Graduate Program in Agricultural Engineering of the Federal University of the Recôncavo Baiano (Programa de Pós-Graduação em Engenharia Agrícola da Universidade Federal do Recôncavo Baiano-PPGEA-UFRB) and was conducted from July to September, 2016, in a greenhouse at the Experimental Station of the UFRB, in Cruz das Almas (latitude, 1240'12" S; longitude, $39^{\circ} 6^{\prime} 7 " \mathrm{~W}$; altitude, 220 $\mathrm{m})$, Bahia, Brazil. According to the classification of D'Angiolella et al. (2000), the climate of the region is humid to subhumid, with a relative humidity of $80 \%$, mean annual temperature of $24{ }^{\circ} \mathrm{C}$, and mean annual rainfall of $1,143 \mathrm{~mm}$.
The study used a completely randomized block design with a $2 \times 2$ factorial scheme, in which the factors were the water source (tap water and treated domestic wastewater) and the height (upper and lower) of the cultivation platforms of the hydroponic system, with eight replications, totaling 32 experimental plots. Each plot included one basil plant (Ocimum basilicum cv. Alfavaca Basilicão) cultivated in a DFT system containing holes with a diameter of $0.05 \mathrm{~m}$ and spaced at $0.20 \mathrm{~m}$.

The experimental design consisted of modules containing hydroponic troughs made of $75-\mathrm{mm}$ irrigation PVC pipes (PN 40) installed horizontally. Each module had a length of $5.40 \mathrm{~m}$ and contained two platforms (upper and lower), and each platform contained two troughs of $6.00 \mathrm{~m}$ in length, with a space of $0.30 \mathrm{~m}$ on each margin of the platform. The platforms were installed one on top of the other, the first being $0.60 \mathrm{~m}$ above the ground (lower) and the other at $0.90 \mathrm{~m}$ above the first (upper), with the troughs spaced $0.30 \mathrm{~m}$ apart.

Basil seeds were obtained from ISLA Seeds and sown in phenolic foam and. At 15 days after sowing (DAS), the seedlings were transported to the hydroponic nursery using the nutrient film technique until the time of transplantation (30 DAS). The seedlings were initially irrigated with tap water (electrical conductivity $[\mathrm{EC}]=$ $0.25 \mathrm{dS} / \mathrm{m}$ ) and, in the nursery stage, with a nutrient solution recommended by Furlani (1998) diluted 50\%. After transplantation to the DFT system, the nutrient solution containing tap water or treated domestic wastewater was applied.

The water used to prepare the solutions came from the municipal water supply system and the sewage treatment plant of the Bahia Water and Sanitation Company (Empresa Baiana de Água e SaneamentoEMBASA) located in the municipality of Muritiba, Bahia, characterized as treated domestic wastewater. A physicalchemical analysis of the effluent was performed, and a screen filter was used at the outlet of the reservoir in the hydroponic system (Table 1).

TABLE 1. Physical-chemical characteristics of the treated domestic wastewater.

\begin{tabular}{ccccccccccccc}
\hline $\mathrm{pH}$ & $\begin{array}{c}\mathrm{EC} \\
\left(\mathrm{dS} \mathrm{m}{ }^{-1}\right)\end{array}$ & $\mathrm{P}$ & $\mathrm{K}$ & $\mathrm{N}$ & $\mathrm{Na}$ & $\mathrm{Ca}$ & $\mathrm{Mg}$ & $\mathrm{Cl}$ & $\mathrm{SO}_{4}$ & $\mathrm{CO}_{3}$ & $\mathrm{HCO}$ & $\begin{array}{c}\mathrm{SAR}^{0.5} \\
\left(\mathrm{mmol} \mathrm{L}^{-1}\right)^{0.5}\end{array}$ \\
\hline 7.1 & 1.0 & 0.05 & 29.3 & 21.8 & 138 & 15 & 18.9 & 175.8 & $\mathrm{~A}$ & $\mathrm{P}$ & 238.5 & 5.5 \\
\hline
\end{tabular}

EC, electrical conductivity; SAR, sodium adsorption ratio. Source: Laboratory of Sanitation of the Federal University of Campina Grande, Campina Grande, Paraíba, Brazil. A, absent; P, present.

To prepare the nutrient solution, each fertilizer was dissolved and transferred to the reservoir to avoid the formation of precipitates. The solution was prepared in a volume of $1000 \mathrm{~L}$, and the $\mathrm{pH}$ and $\mathrm{EC}$ were monitored every two days. When necessary, the $\mathrm{pH}$ was corrected by adding hydrochloric acid diluted $30 \%$ or sodium hydroxide (20.0 $\mathrm{g} \mathrm{L}^{-1}$ ), keeping the $\mathrm{pH}$ value between 5.5 and 6.5. In the study period, the nutrients in the solution were replaced only in the treatments with tap water.

For oxygenation and replacement of the volume consumed in the hydroponic system, the nutrient solution was recirculated automatically using an analog timer at intervals of $2 \mathrm{~h}$ and lasting $15 \mathrm{~min}$. The solution traveled through the root system of the plants and returned to the reservoir, promoting the constant recirculation of the solution.
The fluorescence of chlorophyll $a$ was measured at 35 days after transplantation using a modulated portable fluorometer OS5p (Opti-Sciences, Hudson, USA), with readings in the middle region of the plant shoot and in the central portion of the leaves at 9:00 a.m. The potential quantum yield of photosystem II (PSII) was calculated after 30 min of adaptation to the dark as $F_{v} / F_{m}=\left(F_{m}-F_{0}\right) / F_{m}$, where $F_{0}$ is the minimum fluorescence excited by a modulated low-intensity red light $\left(0.03 \mu \mathrm{mol} \mathrm{m}{ }^{-1} \mathrm{~s}^{-1}\right)$ and $\mathrm{F}_{\mathrm{m}}$ is the maximum fluorescence obtained with a pulse of $0.8 \mathrm{~s}$ of saturating actinic light $\left(>6000 \mu \mathrm{mol} \mathrm{m}^{-1} \mathrm{~s}^{-1}\right)$. The quantum yield of photochemical energy conversion in PSII (Y $\mathrm{Y}_{\text {II }}$, quantum yield of light-regulated non-photochemical energy dissipation in PSII $\left(\mathrm{Y}_{\mathrm{NPQ}}\right)$, and quantum yield of non-regulated non-photochemical energy dissipation in 
PSII $\left(\mathrm{Y}_{\mathrm{NO}}\right)$ were determined according to Kramer et al. (2004) and Klughammer \& Schreiber (2008). Y YI was used to estimate the apparent electron transport rate (ETR) according to Bilger et al. (1995): $\mathrm{ETR}=\mathrm{Y}_{\mathrm{II}} \times \mathrm{PFD} \times 0.5 \times$ 0.84 , where PFD is the photon flux density $\left(\mu \mathrm{mol} \mathrm{m} \mathrm{m}^{-1} \mathrm{~s}^{-1}\right)$ incident on the leaves, 0.5 is the percentage of the excitation energy distributed to PSII, and 0.84 is the percentage of incident light absorbed by the leaves.

The results were subjected to analysis of variance for the sources of variation and interaction using the F-test and the ExpDes.pt package (Ferreira et al., 2013) from the software $\mathrm{R}$ version 3.4.1 ( $\mathrm{R}$ core Team, 2017). The parameters with a significant effect on the sources of variation (water source and platform height) and the interaction (water source $\times$ platform height) were subjected to the comparison of means using the Tukey's test at a level of significance of $5 \%$.

\section{RESULTS AND DISCUSSION}

The analysis of variance of chlorophyll fluorescence in basil plants indicated a significant effect $(\mathrm{p}<0.05)$ on the factors alone and on the interaction water source $\times$ platform height. The water source had a significant effect on $\mathrm{F}_{0}$ and $\mathrm{Y}_{\mathrm{NO}}$ whereas platform height significantly affected $\mathrm{Y}_{\mathrm{II}}, \mathrm{Y}_{\mathrm{NPQ}}, \mathrm{Y}_{\mathrm{NO}}$, and ETR. The interaction water source $\times$ platform height strongly affected $\mathrm{Y}_{\mathrm{NO}}$ (Table 2).

Plants subjected to adverse conditions (biotic or abiotic factors) during growth undergo changes in the function of the thylakoid membranes of the chloroplasts, leading to modifications in the characteristics of the fluorescence signals in the leaves (Baker, 2008). Therefore, the parameters related to chlorophyll $a$ fluorescence measured in basil leaves indicated changes in the photosynthetic yield of the plants caused by the water source and platform height.

TABLE 2. Summary of the analysis of variance of minimum fluorescence $\left(F_{0}\right)$, maximum fluorescence $\left(F_{m}\right)$, potential quantum yield $\left(\mathrm{F}_{\mathrm{v}} / \mathrm{F}_{\mathrm{m}}\right)$, quantum yield of photochemical energy conversion in photosystem II (PSII) (Y $\left.\mathrm{Y}_{\mathrm{II}}\right)$, quantum yield of light-regulated non-photochemical energy dissipation in PSII ( $\left.\mathrm{Y}_{\mathrm{NPQ}}\right)$, quantum yield of non-regulated non-photochemical energy dissipation in PSII ( $\mathrm{Y}_{\mathrm{NO}}$ ), and apparent electron transport rate (ETR) of basil plants (Ocimum basilicum cv. Alfavaca Basilicão).

\begin{tabular}{|c|c|c|c|c|c|c|c|c|}
\hline \multirow{2}{*}{$\begin{array}{l}\text { Source of } \\
\text { variation }\end{array}$} & \multirow{2}{*}{ DF } & \multicolumn{7}{|c|}{ Mean square } \\
\hline & & $F_{0}$ & $\mathbf{F}_{\mathbf{m}}$ & $\mathbf{F}_{\mathrm{v}} / \mathbf{F}_{\mathrm{m}}$ & $Y_{I I}$ & $\mathbf{Y}_{\mathrm{NO}}$ & $\mathbf{Y}_{\mathrm{NPQ}}$ & ETR \\
\hline Water (A) & 1 & $561.12 *$ & $16,200.00$ & $5.00 \mathrm{e}-07$ & 0.00 & $0.00 *$ & 0.00 & $2,292.00$ \\
\hline Position (P) & 1 & 231.13 & $14,280.50$ & $6.12 \mathrm{e}-06$ & $0.04^{*}$ & $0.00 *$ & $0.03 *$ & $36,003.00 *$ \\
\hline $\mathrm{A} \times \mathrm{P}$ & 1 & 465.12 & 435.10 & $7.20 \mathrm{e}-05$ & 0.00 & $0.00 *$ & 0.00 & $2,137.00$ \\
\hline Residual & 28 & 124.34 & $5,803.8$ & $6.76 \mathrm{e}-05$ & 0.00 & 0.00 & 0.00 & $2,831.00$ \\
\hline CV (\%) & & 5.44 & 6.43 & 0.99 & 28.46 & 8.07 & 7.98 & 28.46 \\
\hline Overall mean & & 204.81 & $1,184.81$ & 0.83 & 0.20 & 0.20 & 0.60 & 186.94 \\
\hline
\end{tabular}

*Significant at a level of probability of $5 \%$ using the F-test; $\mathrm{CV}$, coefficient of variation.

Basil plants grown with treated domestic wastewater presented a minimum fluorescence $\left(\mathrm{F}_{0}\right) \quad 4 \%$ higher than that of plants cultivated with tap water (Figure 1). $F_{0}$ is the fluorescence measured when the primary electron-acceptor quinone is fully oxidized, and the PSII reaction center is open, and this state precedes the activation of photochemical reactions. The increase in $\mathrm{F}_{0}$ reflects changes in the PSII reaction center or a decrease in the transfer capacity of the excitation energy from the antenna to the reaction center (Baker, 2008).

The obtained results suggest that chlorophyll molecules in plants grown with a nutrient solution containing treated domestic wastewater may be damaged, leading to changes in PSII caused by water quality. However, $F_{0}$ appears at the stage of fast fluorescence response and should be analyzed together with the other fluorescence parameters for a better analysis of the results. In addition, the results of other studies on alterations in $\mathrm{F}_{0}$ values in cultures under different stresses are controversial. Some studies found that mean $\mathrm{F}_{0}$ values increased proportionally to stress levels whereas other studies did not find a significant difference between these values (Bressan, 2015; Silva et al., 2015; Sousa et al., 2016).

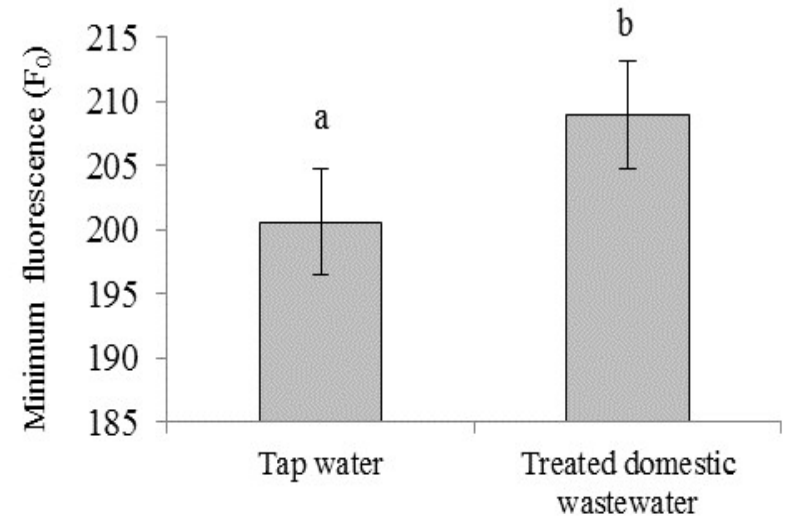

FIGURE 1. Mean minimum fluorescence $\left(\mathrm{F}_{0}\right)$ in basil cv. Alfavaca Basilicão cultivated in a hydroponic system with two water sources. The bars correspond to the standard error. The means followed by the same letter were not significantly different from each other using the Tukey's test $(\mathrm{p}>0.05)$.

With regard to the maximum fluorescence $\left(\mathrm{F}_{\mathrm{m}}\right)$ and the potential quantum yield of PSII $\left(\mathrm{F}_{\mathrm{v}} / \mathrm{F}_{\mathrm{m}}\right)$, there was no significant difference between the means caused by the factors in isolation or in combination. 
$\mathrm{F}_{\mathrm{v}} / \mathrm{F}_{\mathrm{m}}$ reflects the maximum performance of PSII and is a good measure of the suitability of this system. The overall mean $\mathrm{F}_{\mathrm{v}} / \mathrm{F}_{\mathrm{m}}$ in basil plants was 0.83 (Table 2). Plant species with an intact photosynthetic apparatus usually have $F_{v} / F_{m}$ values in the range of 0.75 to 0.85 (Bolhàr-Nordenkampf et al., 1989). The obtained results indicate that basil plants did not present photoinhibition and corroborate the results of Bressan (2015) in basil cv. Genovese, in which there was no significant change in $\mathrm{F}_{\mathrm{v}} / \mathrm{F}_{\mathrm{m}}$ as a function of the water quality (deionized or reused). The small difference $(4 \%)$ in the mean $\mathrm{F}_{0}$ values between the treatments indicates that this difference has little correlation with the water source because the $F_{v} / F_{m}$ values demonstrated the high efficiency and the preserved structure of PSII in both treatments (Table 2).

The $\mathrm{Y}_{\mathrm{II}}$ of plants produced on the lower platform of the hydroponic system was approximately 30\% lower than that of plants grown on the upper platform (Figure 2). Yield is determined by the ability of the photosynthetic apparatus to remove electrons from the electron-acceptor quinone and is directly related to the rate of consumption of the products of photosynthetic electron transport (ATP and NADPH) (Baker, 2008).
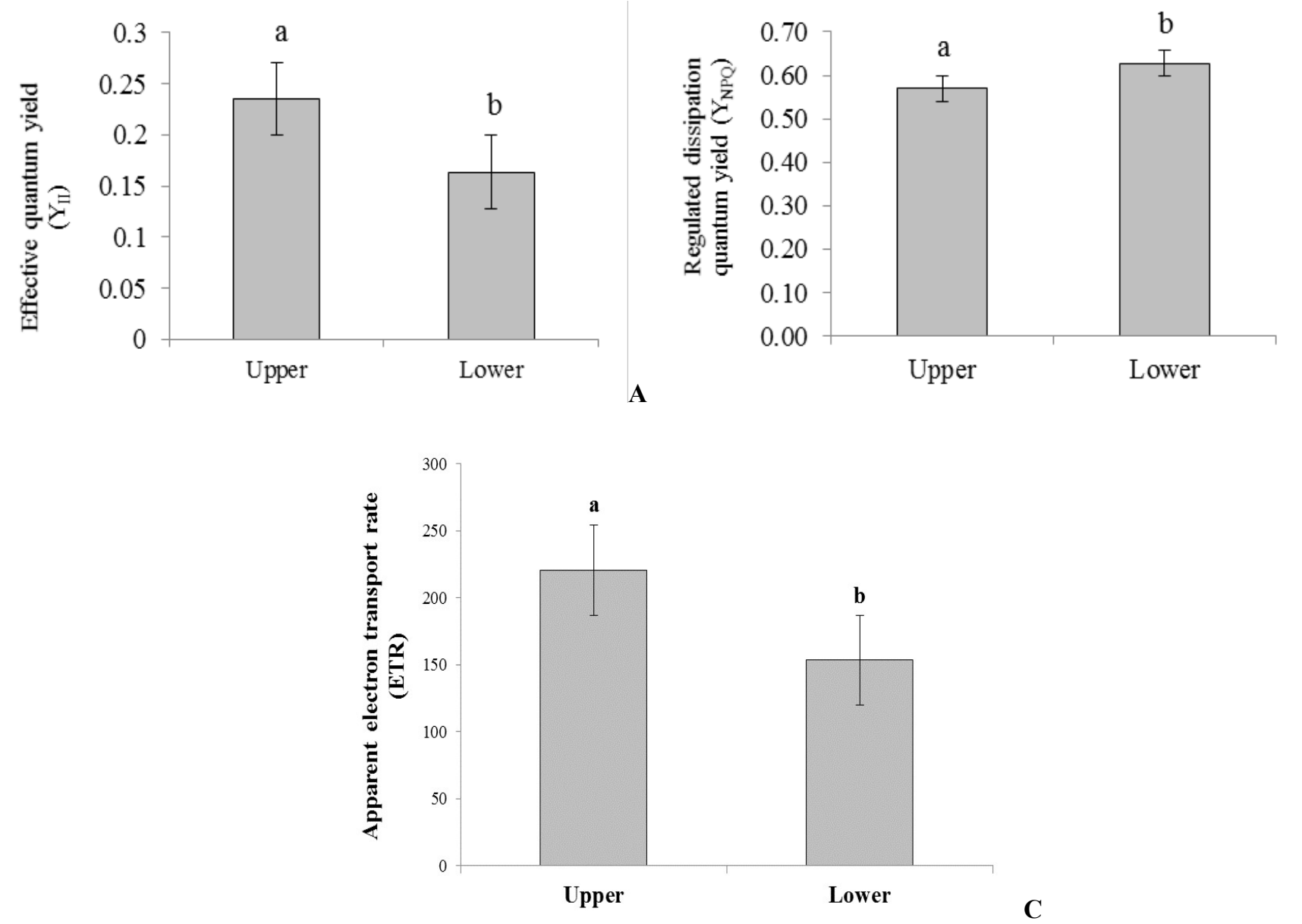

FIGURE 2. Mean values of the quantum yield of photochemical energy conversion in photosystem II (PSII) (Y $\mathrm{Y}_{\text {II }}$ (A), quantum yield of light-regulated non-photochemical energy dissipation in PSII ( $\mathrm{Y}_{\mathrm{NPQ}}$ ) (B), and apparent electron transport rate (ETR) (C) in basil cv. Alfavaca Basilicão cultivated in a hydroponic system with different water sources. The bars correspond to the standard error. The means followed by the same letter were not significantly different from each other using the Tukey's test $(\mathrm{p}>0.05)$.

$\mathrm{Y}_{\mathrm{II}}$ indicates the proportion of energy absorbed by chlorophyll in PSII and used in photochemical activity, i.e., the number of transported electrons and consequently the photosynthetic yield. The remaining fraction $\left(1, \mathrm{Y}_{\text {II }}\right)$ is the total quantum yield of electron loss processes, including $\mathrm{Y}_{\mathrm{NO}}$, which is the fraction of passively dissipated energy in the form of heat and fluorescence (Klughammer \& Schreiber, 2008), and $\mathrm{Y}_{\mathrm{NPQ}}$, which corresponds to lightinduced photoprotection via heat dissipation (Roháček \& Barták, 1999).

The significant reduction of $\mathrm{Y}_{\mathrm{II}}$ in the plants produced on the lower platform indicates the decrease in the carboxylation efficiency, which may have affected the rate of consumption of ATP and NADPH. Therefore, the limited consumption of electrons caused a significant increase in $\mathrm{Y}_{\mathrm{NPQ}}$ (Figure 2) and $\mathrm{Y}_{\mathrm{NO}}$ in plants grown with tap water (Table 3), demonstrating the inability of these plants to protect against light damage.

These results corroborate those found in other studies in cultures subjected to environmental stresses, including sunflower genotypes cultured in $100 \mathrm{mM} \mathrm{NaCl}$ (Azevedo Neto et al., 2011) and coffee cultivars grown under aluminum stress (Konrad et al., 2005).

The ETR was also reduced in plants produced on the lower platform of the hydroponic system, causing a substantial reduction in the transport of electrons to fix 
$\mathrm{CO}_{2}$ (Figure 2). These results confirm previous studies, in which ETR was decreased in stressed plants, including coffee cultivars grown under aluminum stress (Konrad et al., 2005) and water-stressed eucalyptus plants (E. grandis v. E. urophylla) (Gonçalves et al., 2015).

$\mathrm{Y}_{\mathrm{NO}}$ did not differ significantly between the water sources used on the upper platform. However, the plants produced on the lower platform presented lower $\mathrm{Y}_{\mathrm{NO}}$ when cultivated with treated domestic wastewater compared with tap water (Table 3), evidencing that wastewater is a potential alternative for the hydroponic cultivation of basil cv. Alfavaca Basilica because lower $\mathrm{Y}_{\mathrm{NO}}$ values reflect the ability of these plants to protect against light damage, whereas the increase in $\mathrm{Y}_{\mathrm{NPQ}}$ (Figure 2) in plants grown on the lower platform indicates strong photoprotection (Roháček \& Barták, 1999).

TABLE 3. Mean values of the quantum yield of non-regulated non-photochemical energy dissipation in photosystem II ( $\left.\mathrm{Y}_{\mathrm{NO}}\right)$ of basil cv. Alfavaca Basilicão cultivated in a hydroponic system using two water sources.

\begin{tabular}{ccc}
\hline Water source & \multicolumn{2}{c}{ Platform position } \\
\cline { 2 - 3 } & Upper & Lower \\
\hline Tap water & $0.20 \mathrm{aA}$ & $0.23 \mathrm{bB}$ \\
Treated domestic wastewater & $0.19 \mathrm{aA}$ & $0.19 \mathrm{aA}$ \\
\hline
\end{tabular}

The means followed by the same lowercase letter in each column and by the same uppercase letters in each line are not different from each other using the Tukey's test at a level of significance of 5\%. Standard error of the mean equal to 0.0058 .

\section{CONCLUSIONS}

- There was no significant effect of the water source used for preparing the nutrient solution on the potential and effective quantum yield of PSII, indicating the absence of changes in the photosynthetic apparatus and photosynthetic yield of basil plants cv. Alfavaca Basilicão cultivated with treated domestic wastewater;

- The effective quantum yield of PSII in plants grown on the lower platform of the hydroponic system was reduced, regardless of the water source;

- The quantum yield of non-regulated nonphotochemical energy dissipation in PSII $\left(\mathrm{Y}_{\mathrm{NO}}\right)$ of plants grown with tap water on the lower platform decreased, demonstrating the inability of these plants to protect against light damage;

- Treated domestic wastewater can be used in hydroponic systems to cultivate basil cv. Alfavaca Basilicão without compromising the photosynthetic yield of the plants.

\section{ACKNOWLEDGMENTS}

We are grateful to the PPGEA-UFRB and the Coordination of Higher-Level Personnel (CAPES) for granting a PNPD/CAPES scholarship.

\section{REFERENCES}

Albuquerque Júnior JE de, Azevedo CAV de, Azevedo MR de QA, Xavier J de F, Monteiro Filho AF (2016) Qualidade de águas residuárias e salobra utilizadas no cultivo hidropônico de três cultivares de alface crespa. Revista Verde de Agroecologia e Desenvolvimento Sustentável 11(2):19-24. DOI:

http://dx.doi.org/10.18378/rvads.v11i2.4569

Alcântara FD de O, Silva TI da, Maciel TCM, Marco CA, Silva FB da (2018) Teor e fitoquímica de óleo essencial de manjericão em diferentes horários de colheita. Revista de Agricultura Neotropical 5(4):1-6.

Araldi R, Corniani N, Tropaldi L, Girotto M, Belapart D, Simões OS, Velini ED (2015) Chlorophyll fluorescence in guanandi tree (Calophyllum brasiliense) after herbicide application. Planta Daninha 33(1):77-82. DOI: http://dx.doi.org/10.1590/S0100-83582015000100009
Azevedo Neto AD de, Pereira PPA, Costa DP, Santos ACC dos (2011) Fluorescência da clorofila como uma ferramenta possível para seleção de tolerância à salinidade em girassol. Revista Ciência Agronômica 42(4):893-897. DOI: http://dx.doi.org/10.1590/S180666902011000400010

Baker NR (2008) Chlorophyll Fluorescence: a probe of photosynthesis in vivo. Annual Review of Plant Biology 59:89-113. DOI:

http://dx.doi.org/10.1146/annurev.arplant.59.032607.092759

Bilger W, Schreiber U, Bock M (1995) Determination of the quantum efficiency of photo system II and of nonphotochemical quenching of chlorophyll fluorescence in the field. Oecologia 102:425-432. DOI:

https://doi.org/10.1007/BF00341354

Bolhàr-Nordenkampf HR, Long SP, Baker NR, Öquist G, Schreider U, Lechner EG (1989) Chlorophyll fluorescence as probe of the photosynthetic competence of leaves in the field: A review of current instrument. Functional Ecology 3:497-514. DOI: https://doi.org/10.2307/2389624

Bressan DF (2015) Água de reuso e seu efeito sobre parâmetros fisiológicos em manjericão (Ocimum basilicum L.). Tese Doutorado, Jaboticabal, Universidade Estadual Paulista.

Cuba R da S, Carmo JR do, Souza CF, Bastos RG (2015) Potencial de efluente de esgoto doméstico tratado como fonte de água e nutrientes no cultivo hidropônico de alface. Revista Ambiente \& Água 10(3):574-586. DOI: http://dx.doi.org/10.4136/ambi-agua. 1575

D’Angiolella GLB, Castro Neto MT, Coelho EF (2000) Tendências climáticas para os Tabuleiros Costeiros da região de Cruz das Almas, Bahia. Revista Bahia Agrícola 4:14-16.

Ferreira EB, Cavalcanti PP, Nogueira DA (2013) ExpDes.pt: Experimental designs pacakge (Portuguese). R package version 1.1.2.

Furlani PR (1998) Instruções para o cultivo de hortaliças de folhas pela técnica de hidroponia NFT. Campinas, IAC, 30p. (Boletim Técnico, 168). 
Gonçalves KS, Sousa A de P, Velini ED (2015) Aplicação de reguladores vegetais e de fosfito de potássio em mudas de eucalipto submetidas à deficiência hídrica. Irriga 20(2):273-285. DOI:

http://dx.doi.org/10.15809/irriga.2015v20n2p273

Klughammer C, Schreiber U (2008) Complementary PSII quantum yield calculated from simple fluorescence parameters measured by PAM fluorometry and saturation pulse method. PAM Application Notes 1:27-35.

Konrad MLF, Silva JAB da, Furlani PF, Machado EC (2005) Trocas gasosas e fluorescência da clorofila em seis cultivares de cafeeiro sob estresse de alumínio. Bragantia 64(3):339-347. DOI: http://dx.doi.org/10.1590/S000687052005000300004

Kramer DM, Johnson G, Kiirats O, Edwards GE (2004) New fluorescence parameters for the determination of QA redox stat and excitation energy fluxes. Photosynthesis Research 79:209-218. DOI: https://doi.org/10.1023/B:PRES.0000015391.99477.0d

Martinazzo EG, Silva DM, Bianchi VJ, Bacarin MA (2012) Fluorescência da clorofila a em plantas de pessegueiro da cultivar maciel enxertada sobre diferentes porta-enxertos. Revista Brasileira de Fruticultura 34(3):678-685. DOI: http://dx.doi.org/10.1590/S010029452012000300005

Oukarroum A, Madidi SE, Schansker G, Strasser RJ (2007) Probing the responses of barley cultivars (Hordeum vulgare L.) by chlorophyll a fluorescence OLKJIP under drought stress and re-watering. Environmental and Experimental Botany 60:438-446. DOI: http://dx.doi.org/ 10.1016/j.envexpbot.2007.01.002
R Core Team (2017) R: A language and environment for statistical computing. R Foundation for Statistical Computing. Available: https://www.R-project.org/.

Roháček K, Barták M (1999) Tehcnique of the modulated chlorophyll fluorescence: basic concepts, useful parameters, and some applications. Photosynthetica 37:339-363. DOI:

https://doi.org/10.1023/A:1007172424619

Sandri D, Rosa R de RB (2017) Atributos químicos do solo irrigado com efluente de esgoto tratado, fertirrigação convencional e água de poço. Irriga 22(1):18-33. DOI: http://dx.doi.org/10.15809/irriga.2017v22n1p18-33

Santos Júnior JA, Gheyi HR, Dias N da S, Medeiros S de S, Filho DHG (2014) Substratos e tempo de renovação da água residuária no crescimento do girassol ornamental em sistema semi-hidroponia. Revista Brasileira de Engenharia Agrícola e Ambiental 18(8):790-797. DOI:

http://dx.doi.org/10.1590/18071929/agriambi.v18n08p790-797

Silva FG da, Dutra WF, Dutra AF, Oliveira IM de, Filgueiras LMB, Melo AS de (2015) Trocas gasosas e fluorescência da clorofila em plantas de berinjela sob lâminas de irrigação. Revista Brasileira de Engenharia Agrícola e Ambiental 19(10):946-952. DOI: http://dx.doi.org/10.1590/1807-1929/agriambi.v19n10p946-952

Sousa JRM de, Gheyi HR, Brito MEB, Lacerda CF de, Silva FV da, Soares FAL (2016) Quantum efficiency of photosystem II and production of orange under salt stress and nitrogen fertilization. Revista Brasileira de Engenharia Agrícola e Ambiental 20(5):434-440. DOI:

http://dx.doi.org/10.1590/1807-1929/agriambi.v20n5p434-440 